\title{
Yapısal Kırılmalar Altında Türkiye'de Ekonomik Büyüme ve Petrol Tüketimi Arasındaki İlişki
}

\author{
Rıdvan KESKİN*
}

\begin{abstract}
$\ddot{O} Z$
Ülkelerin gelişmişlik düzeyi, enerji tüketim miktarı ile doğru orantılıdır. Yapılan literatür çalışmasında, Türkiye için yapısal kırılmaları dikkate alan 2015 ve 2016 yıllarını da kapsayan bir bilimsel çalışma bulunamamıştır. Bu çalışmanın amacı, yapısal kırılmalar altında Türkiye'de ekonomik büyüme ve petrol tüketimi arasındaki ilişkiyi, 1980-2016 yıllarl arasındaki veri seti kullanılarak ekonometrik analizlerle incelemektir. Elde edilen analiz sonuçlarında, değişkenler arasında uzun dönemli bir ilişkiye rastlanılmıştır. Ayrıca değişkenler arasındaki nedensellik ilişsisini belirlemek amactyla Toda Yamamoto nedensellik testi uygulanmıştır. Bu testin sonucunda, petrol tüketiminden, ekonomik büyümeye doğru tek yönlü bir nedensellik ilişkisi mevcuttur.
\end{abstract}

Anahtar kelimeler: Petrol Tüketimi, Ekonomik Büyüme, Yapısal Kırllma.

Jel kodlart: E2, Q4, O13, C01.

\section{The Relationship between Economic Growth and Petroleum Consumption in Turkey under Structural Breaks}

\begin{abstract}
There is a linear relationship between the development level of a country and its energy consumption. Based on a comprehensive literature review, the authors of the study find that there is a lack of research incorporating the role of structural breaks spanning 2015 and 2016 for Turkey. The purpose of this study is to investigate the relationship between economic growth and petroleum consumption in Turkey under structural breaks through econometric analyses based on a 1980-2016 data set. The findings of the study point to a long-term relationship between the research variables. Toda-Yamamoto causality test is conducted and the analysis reveals a unidirectional causality running from petroleum consumption to economic growth.
\end{abstract}

Keywords: Petroleum Consumption, Economic Grawth, structural breaks.

Jel Classification: E2, Q4, O13, CO1.

\section{GíRIŞ}

Ülkelerin gelişmişlik düzeyi, enerji tüketim miktarı ile doğru orantılıdır (Çemrek ve Burhan, 2014:48). Ülkelerin gelişmişlik düzeyine göre teknolojik gelişmeler enerji tüketimini de arttırmaktadır. Ancak teknolojik gelişmeler ekonomiye genellikle olumlu yönde ve büyük ölçüde etki yapmaktadır (Demir, 1981:14-35). 2015 yılında gelişen ülkeler kategorisinde görülen Türkiye'de enerji

\footnotetext{
* Yrd. Doç. Dr., Manisa Celal Bayar Üniversitesi IÏBF Ekonometri Bölümü ridvan.keskin@ @bu.edu.tr
} 
tüketiminin önceki yıllara göre arttı̆̆ görülmüştür (British Petroleum (BP) Statistical Review of World Energy, 2016:9-11). Bp 2016 kaynaklı araştırmaya göre, 2015 yılında küresel enerji tüketimi yine düşük kalmaya devam etmiştir. Kullanılan yakıtlar kömür ve petrolden düşük karbonlu yakıtlara (yenilenebilir enerji türleri rüzgâr ve güneş enerji kaynaklara) çekildi.

Yenilenemez enerji kaynağı olan petrol sınırlı kaynağa sahip iken (Çukurçayır ve Sağır, 2008:258), petrol tüketimini sınırlandırmak neredeyse imkansızdır. Doğal olarak, ülkelerin teknolojik gelişmelerine paralel olarak petrol tüketimide giderek artmaktadır. Petrolden elde edilen ana ürünler; petrokimyasal ürünler, asfalt, mazot, fuel oil, benzin, gaz yağı, sıvılaştııılmış petrol gazı (LPG), kayganlaştırıcı maddeler, parafin ve katrandır (http://petrolpetroleum.blogspot.com.tr/p/petrol-urunleri.html, 2017).

. Bu ürünler kullanılarak petrol türevlerinden birçok yan ürünlerde elde edilmekte ve günlük yaşamın her alanında kullanılmaktadır. Dünyada olduğu gibi Türkiye'de de, bu durum petrol tüketiminin kullanım sınırlarının sürekli artması şeklinde gözlemlenmektedir. Petrol tüketimi en çok teknolojik gelişmelere bağımlı olan sanayi, taşımacılık, konutsal ve bireysel tüketimi içine alan alanlarında olmaktadir.

Bp Dünya Enerji İstatistikleri 2016 raporuna göre, 2015 yılında dünya çapında enerji tüketiminin yavaşladığı, dünya enerjisinin \%1'ini kullanan Türkiye'de 2015 y1lında doğalgaz ve kömür tüketimi azalırken, petrol ve yenilenebilir enerji tüketiminin arttığı görülmüştür. Aynı raporda dünya çapında petrol tüketimi, \% 1,9 ile yakın tarih ortalamasının neredeyse 2 katı artarak günde 1,9 milyon varile yükselmiştir. Türkiye'de ise petrol tüketimi \%12,5'lik artışla, dünya çapında petrol tüketiminin \% 0,9'luk payına sahip olmuştur.

Gelişmiş ya da gelişmekte olan ülkelerin enerji tüketimi, teknoloji gelişmeler nedeniyle giderek artmaktadır. Ülkemizdeki enerji tüketim miktarının her geçen yıl artması, gelişmekte olan bir ülke olduğunun göstergesidir. Aynı zamanda dünya üretilebilir petrol ve doğal gaz rezervlerinin yaklaşık \%72'lik bölümü, ülkemizin yakın coğrafyasında yer almaktadır. Bu durum ülkemizi, üretici ülkeler (Hazar, Orta Asya, Orta Doğu) ile Avrupa'daki tüketici pazarlar arasında doğal bir "Enerji Merkezi" konumuna getirmektedir. Bu durumlar açısından bakıldığında enerji tüketimini ve ekonomik büyüme arasındaki ilişkinin belirlenmesi gerek iç gerekse dış politikalar bakımından oldukça önem teşkil etmektedir (http://www.enerji.gov.tr/tr-TR/Sayfalar/Petrol, 2017).

Enerji tüketimi ve ekonomik büyüme arasındaki ilişkiyi araştıran çalışmalar sonucunda çeşitli enerji politikaları ortaya çıkmıştır. Öztürk'ün 2010 y1lındaki "A literatüre Survey on Energy-Growth Nexus" adlı makalesinde enerji tüketimi (elektrik tüketimi) ve ekonomik büyüme arasındaki nedensellik ilişkisinin yönüne ile ilgili dört politika ve bu politikalara dayanan dört hipotez yer almaktadır. Bu politika ve hipotezler;

i. Nedensellik yok (No causality): Enerji tüketimi ile ekonomk büyüme arasında nedensellik ilişkisinin olmaması durumudur. Bu durum "tarafsızlı 
hipotezi” olarak adlandırılır. Enerji tüketimini arttırma ya da azaltmaya yönelik politikaların ekonomik büyümeye etkisinin olmayacağını gösterir.

ii. Ekonomik büyümeden enerji tüketimine doğru tek yönlü nedensellik (The uni-directional causality running from economic growth to energy consumption): "Koruma hipotezi" olarak adlandırılır. Bu hipotez, ekonomik büyümede bir artışın olması durumunda enerji tüketiminde de bir artışın olacağını gösterir. Enerji tüketimini koruma politlkaları, ekonomik büyüme üzerine çok küçük veya hiçbir etkiye neden olmayacaktır.

iii. Enerji tüketiminden ekonomik büyümeye doğru tek yönlü nedensellik (The uni-directional causality running from energy consumption to economic growth): " Büyüme hipotezi” olarak adlandırılır. Bu hipotez, enerji tüketimindeki artış ekonomik büyümeye katkı sağlayabilirken, enerji tüketimindeki sınırlamalar ekonomik büyüme üzerinde ters etkiye sahip olabileceğini gösterir. Aynı zamanda bu hipotez, enerji tüketiminin emek ve sermayeyi tamamlayıcı olarak hem doğrudan hem de dolaylı olarak üretim sürecinde ekonomik büyümede önemli bir rol oynadığını gösterir. Bu durumda politika yapıcılar enerji tüketimini arttırmaya yönelik politikalar uygulaması ekonomik büyümeyi de artıracaktır.

iv. Enerji tüketimi ve ekonomik büyümeye arasında çift yönlü nedensellik (Bi-directional causality between energy consumption and economic growth). "Geri bildirim hipotezi" olarak adlandırılır. Enerji tüketimi ve ekonomik büyümedeki değişimler aynı anda olur. Birinde gerçekleşen artış, diğerinde artışa, azalış diğerinde azalışa neden olacaktır. Politik kararlar alınırken bu nedensellik ilişkisine dikkat edilmelidir.

$\mathrm{Bu}$ çalışma beş bölümden oluşmaktadır. İkinci bölümünde literatür taraması yer almaktadır. Bu bölümde, enerji tüketimi ile ekonomik büyüme arasındaki ilişkilerin yönlerine ait hipotezler, yöntemler ve analiz sonuçlarına yer verilmiştir. Üçüncü bölümde metodoloji yer almaktadır. Dördüncü bölümde veri seti ve uygulama kısmına ait bilgiler yer almaktadır. Çalışmanın son bölümü sonuç kısmını oluşturmaktadır.

\section{LITERATÜR}

Kapsamlı bir literatür taraması yapıldığında, petrol tüketimi ve büyüme arasındaki ilişkiyi analiz eden birçok çalışmanın yapılmış olduğu görülmektedir. Tablo 1'de petrol tüketimi ve büyüme değişkenleri arasındaki ilişkiyi ele alan, ulusal yazında ve dünyada yapılmış çalışmalar yer almaktadır. Aynı zamanda ilgili tablonun son sütununda çalışma sonucu ile ilgili hipotezler yer almaktadır. 
Tablo 1. Literatür Araștırması

\begin{tabular}{|c|c|c|c|c|c|c|c|}
\hline Yazar & $\begin{array}{c}\text { Yayın } \\
\text { Yilı }\end{array}$ & Ülkeler & $\begin{array}{l}\text { Çalışmaya } \\
\text { Ait Dönem }\end{array}$ & Değişkenler & Yöntem & Sonuç ve Açıklama & Hipotez \\
\hline $\begin{array}{l}\text { Amano ve } \\
\text { Van Norden }\end{array}$ & 1998 & $\begin{array}{c}\text { ABD,Japon } \\
\text { ya ve } \\
\text { Almanya }\end{array}$ & $\begin{array}{l}1973: 1- \\
1993: 6\end{array}$ & $\begin{array}{l}\text { Petrol Tüketimi ve } \\
\text { Büyüme }\end{array}$ & $\begin{array}{c}\text { Nedensellik } \\
\text { Analizi }\end{array}$ & $\begin{array}{l}\text { Çalışma sonucunda } \\
\text { değişkenler arasında çift } \\
\text { yönlü bir nedensellik } \\
\text { ilişkisine rastlanılmıştır. }\end{array}$ & Geribildirim \\
\hline Yang & 2000 & Tayvan & 1954-1997 & $\begin{array}{l}\text { Enerji Tüketimi: } \\
\text { Petrol, kömür, } \\
\text { doğalgaz, elektrik- } \\
\text { GSYİH* }\end{array}$ & $\begin{array}{c}\text { Granger } \\
\text { Nedensellik } \\
\text { Analizi }\end{array}$ & $\begin{array}{l}\text { Çalışma sonucunda enerji } \\
\text { tüketimi ve büyüme arasında } \\
\text { çift yönlü bir ilişki tespit } \\
\text { edilmiştir. Ayrıca } \\
\text { büyümeden petrol } \\
\text { tüketimine doğru tek yönlü } \\
\text { bir nedensellik ilişkisi } \\
\text { mevcuttur. }\end{array}$ & Geribildirim \\
\hline $\begin{array}{l}\text { Aqeel ve } \\
\text { Butt }\end{array}$ & 2001 & Pakistan & 1955-1996 & $\begin{array}{l}\text { GSYİH, İstihdam } \\
\text { Oranı, Elektrik } \\
\text { Tüketimi, Petrol } \\
\text { Tüketimi }\end{array}$ & $\begin{array}{c}\text { Nedensellik } \\
\text { Analizi }\end{array}$ & $\begin{array}{l}\text { Çalışmada elektrik tüketimi } \\
\text { ile büyüme arasında tek } \\
\text { taraflı bir nedensellik } \\
\text { ilişkisine bulunmuştur. } \\
\text { Diğer değişkenler arasında bir } \\
\text { ilişkiye rastlanılmamıştır }\end{array}$ & $\begin{array}{c}\text { Tek yönlü } \\
\text { Nedensellik } \\
\text { Yok }\end{array}$ \\
\hline $\begin{array}{l}\text { Soytaş ve } \\
\text { Sarı }\end{array}$ & 2003 & Türkiye & 1950-1992 & $\begin{array}{c}\text { Enerji Tüketimi ve } \\
\text { GSYİH }\end{array}$ & $\begin{array}{c}\text { Granger } \\
\text { Nedensellik } \\
\text { Analizi }\end{array}$ & $\begin{array}{l}\text { Çalışmada enerji tüketimi ile } \\
\text { ekonomik büyüme arasında } \\
\text { tek taraflı bir nedensellik } \\
\text { tespit edilmiştir. }\end{array}$ & Tek yönlü \\
\hline $\begin{array}{c}\text { Jimenez- } \\
\text { Rodriguez } \\
\text { ve Sanchez }\end{array}$ & 2004 & $\begin{array}{c}\text { Seçilmiş } \\
\text { Bazı OECD } \\
\text { ülkeleri }\end{array}$ & $\begin{array}{l}1972 Q_{3-}^{-} \\
2001 Q_{4}\end{array}$ & $\begin{array}{l}\text { Petrol Fiyatları ile } \\
\text { Ekonomik Büyüme }\end{array}$ & $\begin{array}{c}\text { Birim Kök } \\
\text { Analizleri ve } \\
\text { Regresyon Analizi }\end{array}$ & $\begin{array}{l}\text { Çalışmada ulaşılan sonuç, } \\
\text { petrol fiy atlarının reel } \\
\text { büyüme üzerinde doğrusal } \\
\text { olmay an bir etkisi } \\
\text { mevcuttur. }\end{array}$ & ---- \\
\hline $\begin{array}{c}\text { Zou ve } \\
\text { Chau }\end{array}$ & 2006 & Çin & 1953-2002 & $\begin{array}{l}\text { Petrol Tüketimi ve } \\
\text { Büyüme }\end{array}$ & $\begin{array}{c}\text { Eşbütünleşme ve } \\
\text { Nedensellik } \\
\text { Analizi }\end{array}$ & $\begin{array}{l}\text { Çalışmada uzun dönemde } \\
\text { değişkenler arasında } \\
\text { nedensellik ilişkisine } \\
\text { rastlanılmıştır. }\end{array}$ & $\begin{array}{c}\text { Nedensellik } \\
\text { yok }\end{array}$ \\
\hline Prasad vd. & 2007 & Fiji Adaları & $1970-2005$ & $\begin{array}{l}\text { Petrol Fiyatları ve } \\
\text { Büyüme }\end{array}$ & Regresyon Analizi & $\begin{array}{l}\text { Çalışmada ulaşılan sonuç, } \\
\text { petrol fiy atlarındaki artışın } \\
\text { reel GSYİH üzerinde, pozitif } \\
\text { etkiye sahiptir. }\end{array}$ & \\
\hline
\end{tabular}


Tablo 1. Devamı

\begin{tabular}{|c|c|c|c|c|c|c|c|}
\hline Yazar & $\begin{array}{c}\text { Yayın } \\
\text { Yllı }\end{array}$ & Ülkeler & $\begin{array}{l}\text { Çalış maya } \\
\text { Ait Dönem }\end{array}$ & Değiş̧kenler & Yöntem & Sonuç ve Açıklama & Hipotez \\
\hline $\begin{array}{l}\text { Aktaş ve } \\
\text { Yılmaz }\end{array}$ & 2008 & Türkiye & 1970-2004 & $\begin{array}{l}\text { Petrol Tüketimi ve } \\
\text { Büyüme }\end{array}$ & $\begin{array}{l}\text { Eşbütünleşme ve } \\
\text { Nedensellik } \\
\text { Analizi }\end{array}$ & $\begin{array}{l}\text { Çalışmada, kısa ve uzun } \\
\text { dönemde petrol tüketimi ve } \\
\text { ekonomik büyüme arasında } \\
\text { çift yönlü nedensellik ilişkisi } \\
\text { tespit edildi. }\end{array}$ & Geribildirim \\
\hline Kandel vd. & 2008 & $\begin{array}{c}\text { ABD ve } \\
\text { Kaliforniya }\end{array}$ & $1980-2005$ & $\begin{array}{l}\text { Kişi Başı GSYiH, } \\
\text { Kiși Başı Elektrik } \\
\text { Tüketimi, Elektrik } \\
\text { Fiyatları, Yakıt ve } \\
\text { Doğal Gaz } \\
\text { Tüketimi }\end{array}$ & Regresyon analizi & $\begin{array}{l}\text { Çalışma da Kaliforniya'nın } \\
\text { ABD’ye göre daha az } \\
\text { elektrik tükettiŏi sonucuna } \\
\text { ulaşılmıştır. }\end{array}$ & ----- \\
\hline Ghosh & 2009 & Hindistan & $1970-2006$ & $\begin{array}{l}\text { Ham Petrol İthalat1, } \\
\text { Fiy at ve Gelir } \\
\text { Esnekliği }\end{array}$ & ARDL sinır testi & $\begin{array}{l}\text { Çalışmada, ham petrol } \\
\text { ithalatının uzun dönem gelir } \\
\text { esnekliğini } 1,975 \text { olarak } \\
\text { bulunurken, fiyat esnekliği } \\
\text { ise istatiksel olarak anlamlı } \\
\text { bulunamamıştır. }\end{array}$ & ------ \\
\hline $\begin{array}{l}\text { Iway emi } \\
\text { vd. }\end{array}$ & 2010 & Nijerya & $1977-2006$ & $\begin{array}{c}\text { Farklı Petrol } \\
\text { Ürünleri Talebi, } \\
\text { Petrol Ürünleri } \\
\text { Talebinin Kısa ve } \\
\text { Uzun dönem Fiyat } \\
\text { ve Gelir Esnekliği }\end{array}$ & $\begin{array}{c}\text { Johansen } \\
\text { Eşbütünleşme } \\
\text { Testi }\end{array}$ & $\begin{array}{l}\text { Çalışmada ulaşılan sonuç } \\
\text { petrol ürünleri için talebin } \\
\text { fiy at ve gelirdeki değişmelere } \\
\text { karşı esnek olmamasıdır. }\end{array}$ & ----- \\
\hline Al-Mulali & 2011 & $\begin{array}{l}\text { Orta Doğu } \\
\text { ve Kuzey } \\
\text { Afrika } \\
\text { Ülkeleri }\end{array}$ & 1980-2009 & $\begin{array}{l}\text { GSYİH-Petrol } \\
\text { Tüketimi-CO }{ }_{2}\end{array}$ & $\begin{array}{l}\text { Pedroni Panel- Eş- } \\
\text { Bütünleşme Testi }\end{array}$ & $\begin{array}{l}\text { Çalışmada büyüme ile petrol } \\
\text { tüketimi arasında çift yönlü } \\
\text { bir ilişki bulunmuştur. }\end{array}$ & Geribildirim \\
\hline $\begin{array}{l}\text { Ceylan ve } \\
\text { Başer }\end{array}$ & 2011 & Türkiye & $1965-2011$ & $\begin{array}{l}\text { GSYIHH-Petrol } \\
\text { Tüketimi- }\end{array}$ & $\begin{array}{c}\text { Eşbütünleşme } \\
\text { Testi ve Granger } \\
\text { Nedensellik Testi }\end{array}$ & $\begin{array}{l}\text { Çalışmada petrol } \\
\text { tüketiminden reel GSYIH'ye } \\
\text { doğru tek yönlü bir ilişki } \\
\text { mevcuttur. }\end{array}$ & Tek yönlü \\
\hline $\begin{array}{c}\text { Hossein ve } \\
\text { Yazdan }\end{array}$ & 2012 & İran & $1980-2010$ & $\begin{array}{l}\text { GSYH-Petrol } \\
\text { Tüketimi }\end{array}$ & $\begin{array}{c}\text { Eşbütünleşme } \\
\text { Testi ve Granger } \\
\text { Nedensellik Testi }\end{array}$ & $\begin{array}{l}\text { Çalışmada kısa dönemde } \\
\text { büyüme den petrol } \\
\text { tüketimine doğru bir } \\
\text { nedensellik ilişsisi mevcut } \\
\text { iken uzun dönemde bir ilişki } \\
\text { bulunamamıştır. }\end{array}$ & $\begin{array}{l}\text { Tek yönlü, } \\
\text { Nedensenlik } \\
\text { Yok }\end{array}$ \\
\hline
\end{tabular}




\begin{tabular}{|c|c|c|c|c|c|c|c|}
\hline \multicolumn{8}{|c|}{ Tablo 1. Devamı } \\
\hline Yazar & $\begin{array}{c}\text { Yayın } \\
\text { Yllı }\end{array}$ & Ülkeler & $\begin{array}{l}\text { Çalışmaya } \\
\text { Ait Dönem }\end{array}$ & Değișkenler & Yöntem & Sonuç ve Açıklama & Hipotez \\
\hline $\begin{array}{c}\text { Mehrara ve } \\
\text { Musai }\end{array}$ & 2012 & $\begin{array}{l}\text { Petrole bağl1 } \\
\text { olarak } \\
\text { gelişmekte } \\
\text { olan } 11 \text { ülke }\end{array}$ & 1970-2010 & $\begin{array}{l}\text { Kişi başına ulusal } \\
\text { gelir, Kişi Başına } \\
\text { Düşen Elektrik } \\
\text { Tüketimi, Petrol } \\
\text { Fiyatı }\end{array}$ & $\begin{array}{c}\text { Panel } \\
\text { Eşbütünleşme } \\
\text { Testleri ve Panel } \\
\text { Nedensellik testi }\end{array}$ & $\begin{array}{l}\text { Çalışmada KB GSYIH ve } \\
\text { petrol fiy atlarından, KB } \\
\text { Elektrik Tüketimine doğru } \\
\text { tek yönlü bir nedensellik } \\
\text { ilişskisi mevcuttur. }\end{array}$ & Tek yönlü \\
\hline $\begin{array}{c}\text { Çemrek ve } \\
\text { Burhan }\end{array}$ & 2014 & Türkiye & $1990-2010$ & $\begin{array}{l}\text { GSYİH ve Petrol } \\
\text { Tüketimi }\end{array}$ & $\begin{array}{c}\text { Panel } \\
\text { Eşbütünleşme } \\
\text { Testleri }\end{array}$ & $\begin{array}{l}\text { Çalışmada değişkenler } \\
\text { arasında uzun dönemde bir } \\
\text { iliş̧ki mevcuttur. }\end{array}$ & -..--. \\
\hline Park ve Yoo & 2014 & Malezya & $1965-2011$ & $\begin{array}{l}\text { GSYİH ve Petrol } \\
\text { Tüketimi }\end{array}$ & $\begin{array}{c}\text { Eşbütünleşme } \\
\text { Testi ve Granger } \\
\text { Nedensellik Testi }\end{array}$ & $\begin{array}{l}\text { Çalış̧mada değişkeler } \\
\text { arasında çift yönlü bir } \\
\text { nedensellik ilişkisi tespit } \\
\text { edilmiştir. }\end{array}$ & Geribildirim \\
\hline $\begin{array}{c}\text { Uçak ve } \\
\text { Usupbeyli }\end{array}$ & 2015 & Türkiye & $1971-2013$ & $\begin{array}{c}\text { GSYH ve Petrol } \\
\text { Tüketimi }\end{array}$ & $\begin{array}{c}\text { Johansen } \\
\text { Eşbütünleşme } \\
\text { Testi ve Granger } \\
\text { Nedensellik testi }\end{array}$ & $\begin{array}{l}\text { Çalışmada değişkenler } \\
\text { arasında uzun dönemli bir } \\
\text { iliş̧ki bulunamamışstır ve } \\
\text { değişkenler arasında } \\
\text { nedensellik ilişkisi tespit } \\
\text { edilememiştir. }\end{array}$ & $\begin{array}{c}\text { Nedensellik } \\
\text { yok }\end{array}$ \\
\hline $\begin{array}{c}\text { Hepaktan } \\
\text { ve Sertkaya }\end{array}$ & 2016 & Türkiye & 1970-2014 & $\begin{array}{l}\text { Kişi başına düşen } \\
\text { elektrik tüketimi, } \\
\text { Kişi başına düşen } \\
\text { GSYIHH, } \mathrm{CO}_{2} \\
\text { emisyonu ve petrol } \\
\text { tüketimi }\end{array}$ & $\begin{array}{c}\text { Eşbütünleşme } \\
\text { Testi, Nedensellik } \\
\text { Testi }\end{array}$ & $\begin{array}{l}\text { Çalışmada bütün } \\
\text { değişkenlerden kişi başına } \\
\text { elektrik tüketimine doğru tek } \\
\text { yönlü bir nedensellik iliş̧kisi } \\
\text { bulunmuştur. Ayrıca petrol } \\
\text { tüketiminden de kişi başına } \\
\text { düşen GSYiH'ya doğru tek } \\
\text { yönlü bir nedensellik ilişkisi } \\
\text { tespit edilmiştir. }\end{array}$ & Tek yönlü \\
\hline
\end{tabular}


Çalışmanın konusu ile ilgili literatür özetine bakıldığında, konuyla ilgili yapılmış çalışmalarda bir görüş birliğine varılamamıştır. Bazı çalışmalarda tek yönlü bir ilişki geçerli iken bazılarında çift yönlü bir ilişki bazılarında ise nedensellik ilişkisi olmadığı görülmektedir.

\section{METODOLOJI்}

\section{A. Birim Kök Analizi}

Serileri durağan hale getirmek için birim kök testleri uygulanmaktadır. Çünkü durağan olmayan serilerin kullanıldığı analizlerde sahte regresyon sorunu ortaya çıkabilir. Bu durumda değişkenler arasında aslında hiç bir ilişki olmamasına rağmen, aralarında ilişki olduğu sonucuna ulaşılabilir. Zaman serisi analizlerinde bu sorunla karşılaşmamak için yapılması öncelikle, modelde kullanılan değişkenlerin durağanlığının tespit edilmesidir. Bir zaman serisi, ortalaması ve varyansı zaman içinde sabit kalıyorsa ve iki dönem arasındaki ortak varyansı bu ortak varyansın hesaplandığı döneme bağlı değildir. Sadece iki dönem arasındaki uzaklığa bağlı olduğu için durağan hale gelmektedir (Gujarati, 2004:798).

Çalışmada geleneksel olarak kullanılan Augmented Dickey-Fuller (ADF) ve Phillips-Perron (PP) testlerinin yanı sıra değişkenler arasındaki tahmin dönemindeki herhangi bir yapısal kırılmanın etkisinin belirlenmesi amaciyla Zivot ve Andrews'in (1992) birim kök testi kullanılmıştır. Sözü edilen birim kök testilerine göre zaman serilerindeki yapısal kırılmalar Perron (1989)'un aksine içsel olarak belirlenmektedir. Zivot-Andrews birim kök testi aşağıdaki 3 modele dayalı olarak yapılmaktadır (Zivot ve Andrews, 1992: 253-4):

\section{Model A:}

$\mathrm{y}_{\mathrm{t}}=\mu+\beta_{\mathrm{t}}+\alpha \mathrm{y}_{\mathrm{t}-1}+\theta_{1} \mathrm{DU}(\phi)+\sum_{i=1}^{k} c_{i} \Delta y_{t-i}+e_{t}$

\section{Model B:}

$\mathrm{y}_{\mathrm{t}}=\mu+\beta_{\mathrm{t}}+\alpha \mathrm{y}_{\mathrm{t}-1}+\theta_{2} \mathrm{DT}(\phi)+\sum_{i=1}^{k}+e_{t}$

(2)

\section{Model C:}

$\mathrm{y}_{\mathrm{t}}=\mu+\beta_{\mathrm{t}}+\alpha \mathrm{y}_{\mathrm{t}-1}+\theta_{2} \mathrm{DT}(\phi)+\theta_{1} \mathrm{DU}(\phi)+\sum_{i=1}^{k} c_{i} \Delta y_{t-i}+e_{t}$

Model A düzeyde, Model $\mathrm{B}$ eğimde, Model $\mathrm{C}$ ise hem eğimde hem de düzeyde görülen yapısal değişimi ifade etmektedir. $t=1,2, \ldots, T$ zamanı, $T_{B}$ kırılma zamanı olmak üzere, $\tau=\mathrm{T}_{\mathrm{B}} / \mathrm{T}$ kırılma noktasını göstermektedir. $\mathrm{DU}, \mathrm{t}>\mathrm{TB}$ olması halinde 1, diğer durumlarda 0 değerini alan ve sabit terimdeki yapısal değişimi gösteren, DT ise $\mathrm{t}>\mathrm{TB}$ iken $\mathrm{t}-\mathrm{TB}$, aksi durumlarda sıfır değerini alan ve trend içerisinde meydana gelen yapısal değişimi gösteren gölge değişkenlerdir. ZivotAndrews (1992) testinde yapısal kırılma içsel olarak, veri setinden faydalanarak 
belirlenmektedir. Bunun için her olası kırılma tarihi için farklı bir gölge değişken kullanılarak, $\mathrm{t}=2, . .,(\mathrm{T}-1)$ için EKK yöntemiyle $\mathrm{T}-2$ sayıda regresyon oluşturulur ve $\mathrm{y}_{\mathrm{t}-1}$ değişkeninin katsayısının en küçük t-istatistiğine sahip olduğu modeldeki tarih uygun yapısal kırılma noktası olarak belirlenir. Uygun kırılma noktası seçildikten sonra, hesaplanan t istatistiği Zivot-Andrews (1992) yılı makalesinde yer alan kritik değerleriyle karşılaştırılır. Bu t istatistiğinin ZA kritik değerinden mutlak değerce küçük olması halinde yapısal kırılma olmadan serinin birim kök içerdiğini gösteren temel hipotez kabul edilir, aksi halde ise yapısal kırılmayla birlikte serinin durağan halde olduğunu ifade eden alternatif hipotez reddedilemez (Şentürk ve Akbaş, 2014:5820-5832).

\section{B.Gregory-Hansen Eşbütünleşme Testi}

Gregory ve Hansen tarafından 1996 yılında yayınlanan çalışmada yer alan yapısal kırılmalı eşbütünleşme testinde değişkenler arasındaki uzun dönemli ilişki üç farklı model aracılığ ile ele alınmıştır. Bu üç model şu şekilde ifade edilmektedir (Gregory ve Hansen, 1996:103).

Model C (Sabitte Kirllma):

$\mathrm{y}_{1 \mathrm{t}}=\mu_{1}+\mu_{2}+\phi_{\mathrm{tc}}+\alpha^{\mathrm{T}}+\mathrm{y}_{2 \mathrm{t}}+\mathrm{e}_{\mathrm{t}}$

$\mathrm{t}=1, \ldots, \mathrm{n}$

şeklinde ifade edilmekte olup modelde $\mu_{1}$ kırılmadan önceki sabit terimi, $\mu_{2}$ ise kırılmanın sabit terimde meydana getirdiği değişikliği belirtmektedir.

Model C/T (Trendli Sabitte Kırılma):

$\mathrm{y}_{1 \mathrm{t}}=\mu_{1}+\mu_{2}+\phi_{\mathrm{t \tau}}+\beta_{\mathrm{t}}+\alpha^{\mathrm{T}}+\mathrm{y}_{2 \mathrm{t}}+\mathrm{e}_{\mathrm{t}} \quad \mathrm{t}=1, \ldots, \mathrm{n}$

şeklindedir. Bu modelde hem sabit terimdeki hem de trenddeki kırılmalar dikkate alınır.

Model C/S (Rejim Değișikliği):

$\mathrm{y}_{1 \mathrm{t}}=\mu_{1}+\mu_{2} \phi_{t \tau}+\alpha_{1}^{\mathrm{T}} \mathrm{y}_{2 \mathrm{t}}+\alpha_{2}^{\mathrm{T}} \mathrm{y}_{2 t} \phi_{t \tau}+\mathrm{e}_{\mathrm{t}}$

$\mathrm{t}=1, \ldots, \mathrm{n}$

şeklinde belirtilirken $\mu_{1}$ ve $\mu_{2}$ sabitte kırılmayı gösteren modelde ifade edildiği gibidir. Burada $\alpha_{1}$ kırılmadan önceki eğim katsayısını, $\alpha_{2}$ ise kırılmadan sonra eğimde meydana gelen değişikliği göstermektedir.

Gregory ve Hansen (1996) eşbütünleşme testinde uygun model seçimi için belirlenen test istatistiklerinin tablo kritik değerleri ile karşılaştırılmaktadır. Yapılan karşılaştırma sonucu, değişkenler arasında ilişkinin olmadığını belirten temel hipoteze oluşturulmaktadır. Bunun yanısıra yapısal kırılmayla beraber değişkenler arasında eşbütünleşme ilişkisinin bulunduğunu ifade eden alternatif hipotez kurulmaktadır. Değişken sayısına göre belirlenen tablo kritik değerleri Gregory ve Hansen (1996)' in yaptıkları çalışmada yer almaktadır (Yardımcıoğlu ve Başel,2013:2197-2211).

\section{Toda-Yamamoto Nedensellik Analizi}

Granger nedensellik testinde spesifik parametrelere, sifir kisitlamalarına yönelik bir ihtiyaç söz konusu olduğu için test istatistiği Wald veya $\chi^{2}$ testi uygulanarak oluşturulmaktadır. Ancak VAR modellerin değişkenlerinin durağan halde bulunmamasının sonucu olarak $F$ veya $\chi^{2}$ dağılımları standart olmayan asimptotik özellikler gösterebilmektedir. Toda ve Yamamoto (1995) çalışmaları sonucunda, VAR modelleri oluşturulurken serilerin durağanlığı ele alınmaksızın 
seviye değerlerinin kullanıldığı ve serilerin arasındaki uzun dönemli ilişkinin dikkate alınmadığı nedensellik analizi geliştirmişlerdir(Lütkepohl ve Kratzig, 2004:148). Toda-Yamamoto yönteminden yararlanılarak analizler elde edilecek bir çalışmada, ilk önce VAR modeli için "uygun gecikme uzunluğu" (p) belirlenmektedir. Daha sonraki aşamada, ise tespit edilen gecikme uzunluğuna (p), en yüksek bütünleşmeye sahip değişkenin "maksimum bütünleşme derecesi" $\left(\mathrm{d}_{\max }\right)$ eklenmektedir. Gecikme uzunluğu $(\mathrm{p})$, maksimum bütünleşme derecesi $\left(\mathrm{d}_{\max }\right)$ olan bir VAR $\left(\mathrm{p}+\mathrm{d}_{\max }\right)$ modelinin tahmin edilmesini gerektirmektedir (Toda ve Yamamoto, 1995: 230).

Toda-Yamamoto yaklaşımında tahmin edilen VAR $(\mathrm{p}+\mathrm{d})$ modeli aşağıdaki gibi tanımlanmaktadır.

$$
\begin{aligned}
& Y_{t}=\alpha_{0}+\sum_{i=1}^{p+d} \alpha_{1(i+d)} Y_{t-(i+d)}+\sum_{i=1}^{p+d} \alpha_{2(i+d)} X_{t-(i+d)}+\varepsilon_{1 t} \\
& X_{t}=\beta_{0}+\sum_{i=1}^{p+d} \beta_{1(i+d)} Y_{t-(i+d)}+\sum_{i=1}^{p} \beta_{2(i+d)} X_{t-(i+d)}+\varepsilon_{2 t}
\end{aligned}
$$

İlk modelde temel hipotez, $\mathrm{H}_{0}: \alpha_{2(i+d)}=0$ olarak belirtilir ve $\mathrm{X}$ değişkeninin, $\mathrm{Y}$ değişkeninin Granger nedeni olmadığını, alternatif hipotez ise $\mathrm{H}_{1}: \alpha_{2(i+d)} \neq 0$ olup, $\mathrm{X}^{\prime}$ in Y'nin Granger nedeni olduğunu gösterir. Bu hipotezler $\mathrm{p}$ serbestlik dereceli $\chi^{2}$ dağılıma uygunluk gösteren Wald testiyle sınanır. Benzer şekilde ikinci model için de analiz yapılır. Burada eklenen ilave terimler $\left(\mathrm{d}_{\max }\right)$ sınırlamaya dahil edilmemektedir (Y1lanc1 ve Özcan,2010:28).

\section{Veri Seti ve Uygulanan Ekonometrik Yöntem}

Türkiye'de petrol tüketimi ile reel GSYİH arasındaki ilişkiyi incelemek amacıyla, ekonometrik bir analiz olan zaman serilerinden faydalanılacaktır. Bu çalışmada 1980-2016 yılları arasındaki yıllık zaman serisi verileri kullanılarak, petrol tüketimi ile reel GSYİH arasındaki ilişki incelenmektedir. Çalışmada kullanılan verilerden petrol tüketimi Word Bank'dan, reel GSYIH TÜIK internet sitesinden elde edilmiştir. Analizlerde kullanılan, LNPT ve LNGSYIH, kısaltma ifadeleri sırasıyla, petrol tüketimi ve reel GSYİH değişkenlerinin doğal logaritmaları alınmış hallerini göstermektedir. Çalışmada kullanılan verilerin tahmini E-Views 9 programı kullanılarak yapılmıştır. Bu verilerin zaman içindeki değişimleri Şekil 1'de görülmektedir. 
Şekil 1. Modelde Yer Alan Serilerin Grafiği LNPT

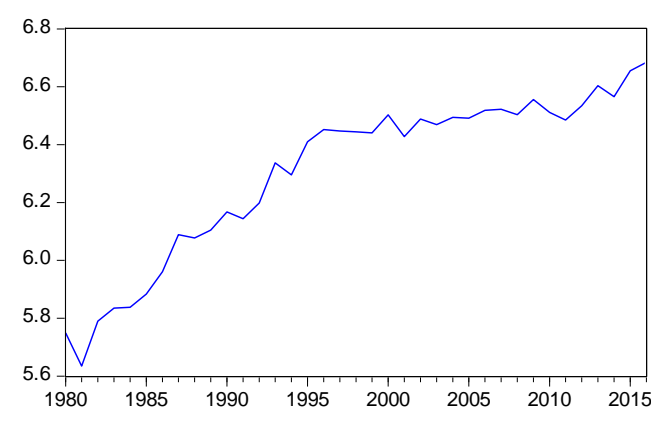

LNGSYIH

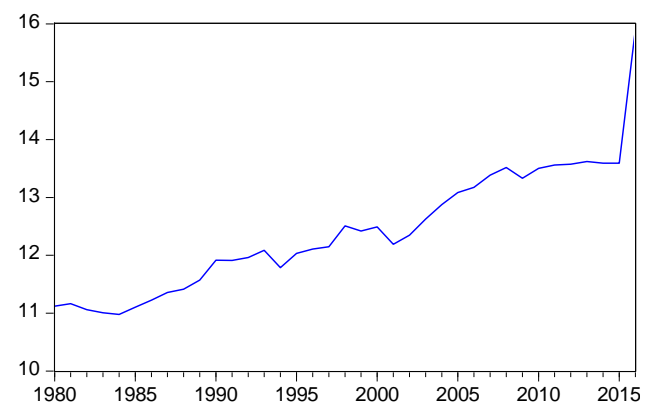

1980 - 2016 arası yıllık petrol tüketimi ve reel GSYİH, değerlerini gösteren Şekil 1'i incelediğimizde, petrol tüketimi serisinin 1981 yılından 2016 yılına kadar istikrarlı bir şekilde arttığını, 2016 yılında en yüksek değerine ulaştığını görebiliriz. Reel GSYİH serisini incelersek, genellikle artan bir seyir göstermesine rağmen bir dalgalanma görülmektedir ve çok sayıda kırılma yaşanmaktadır. 2015 yılına kadar artış eğilimde olan seri 2015 yılında ani bir artış göstermiştir. En yüksek değerine ise 2016 yılında ulaşmaktadır. Serilerde artış ve azalmalar görülse bile, bazı dönemlerde yapısal kırılmalar olduğu görülmektedir.

\section{Birim Kök Testleri}

Tablo 2, petrol tüketimi ile reel GSYİH değişkenlerine ait ADF ve PP birim kök testi sonuçlarını göstermektedir.

ADF Birim kök testine ilişkin boş ve alternatif hipotez şöyle oluşturulmaktadır: $\mathrm{H}_{0}$ : Seri durağan değildir (birim kök içermektedir).

$\mathrm{H}_{1}$ : Seri durağandır (birim kök içermemektedir). 
Tablo 2. ADF ve PP Birim Birim Kök Testi Sonuçları

\begin{tabular}{|c|c|c|c|}
\hline \multicolumn{2}{|c|}{ ADF TESTI } & LNPT & LNGSYIH \\
\hline \multirow{2}{*}{ Düzeyde } & Sabit Trendli & -3.71 & -0.24 \\
\cline { 2 - 4 } & Sabit & -1.38 & -3.08 \\
\hline \multirow{2}{*}{ 1. fark } & Sabit Trendli & $-8.42^{* *}$ & $-6.09^{* *}$ \\
\cline { 2 - 4 } & Sabit & $-9.98^{* *}$ & $-6.02^{* *}$ \\
\hline \multirow{2}{*}{ PP TESTİ } & LNPT & LNGSYIH \\
\hline \multirow{2}{*}{ Düzeyde } & Sabit Trendli & -1.97 & -0.24 \\
\cline { 2 - 5 } & Sabit & -0.98 & -3.06 \\
\hline \multirow{2}{*}{ 1. fark } & Sabit Trendli & $-7.98^{* *}$ & $-6.09 * *$ \\
\cline { 2 - 5 } & Sabit & $-11.6 * *$ & $-6.03 * *$ \\
\hline \multirow{2}{*}{ Kritik Değerler } & Sabit & Sabit Trendli & Sabit \\
\hline$\% 1$ & -3.485 & -4.035 & -3.483 \\
\hline$\% 5$ & -2.885 & -3.447 & -2.884 \\
\hline
\end{tabular}

Not: ADF ve PP Testi kritik değerleri \% 1 ve \% 5 anlam düzeyindeki MacKinnon (1996) kritik değerlerini ifade etmektedir. * değerleri $\% 1$ anlamlılık düzeyini, **\% 5 anlam düzeyindeki ifade etmektedir.

Tablo 2'de yer alan ADF ve PP test sonuçlarına göre, birim kök testi sınamasında değişkenler birinci farklarında durağandır. Başka bir ifadeyle serilerin birinci farkı alındığında sıfır hipotezi red edilerek durağan hale geldiği görülmektedir. Dolayısıyla hem ADF hem de PP test sonuçlarına göre değişkenler birinci farklarında durağandır.

Uygulamada yaygın kullanım alanı bulan ADF ve PP testleri serilerde kırılma ihtimalini dikkate almayan testlerdir. Bu nedenle çalışmada geleneksel birim kök testlerine ek olarak Zivot ve Andrews (1992)'in yapısal kırılmaya izin veren birim kök testi gerçekleştirilmiştir. Tablo 3 'te görülen test istatistiği kritik değerleri Zivot-Andrews'in (1992) çalışmasından alınmıştır.

Tablo 3. Zivot-Andrews Birim Kök Testi Sonuçları

\begin{tabular}{|c|c|c|c|c|c|c|}
\hline Değişkenler & $\begin{array}{c}t \text { ist } \\
\text { Model A }\end{array}$ & $\begin{array}{c}\text { Model A } \\
\text { Kırılma } \\
\text { Dönemi }\end{array}$ & $\begin{array}{c}t \text { ist } \\
\text { Model B }\end{array}$ & $\begin{array}{c}\text { Model B } \\
\text { Kirılma } \\
\text { Dönemi }\end{array}$ & $\begin{array}{c}t \text { ist } \\
\text { Model C }\end{array}$ & $\begin{array}{c}\text { Model C } \\
\text { Kurılma } \\
\text { Dönemi }\end{array}$ \\
\hline LNPT & $-2,76$ & 1990 & $-2,71$ & 2000 & -3.11 & 2001 \\
\hline LNGSYİH & -2.44 & 1997 & -3.9 & 2001 & -3.28 & 2006 \\
\hline$\Delta$ LNPT & -9.65 & 1994 & -6.47 & 2003 & $-8,7$ & 2009 \\
\hline$\Delta$ LLGSYİH & -8.91 & 2001 & -7.72 & 2007 & -7.91 & 2009 \\
\hline $\begin{array}{c}\text { Kritik } \\
\text { Değerler }\end{array}$ & Model A & & Model B & & Model C & \\
\hline$\% 1$ & $-5,34$ & & $-4,80$ & & $-5,57$ & \\
\hline$\% 5$ & $-4,93$ & & $-4,42$ & & $-5,08$ & \\
\hline$\% 10$ & $-4,58$ & & $-4,11$ & & $-4,82$ & \\
\hline
\end{tabular}


Tablo 3'te Model A serilerin sabitinde kırılmayı, Model B trend de kırılmayı ve Model C ise sabit ve trend de kırılmayı araştırmaktadır. Zivot-Andrews testi sonuçlarına göre; değişkenlerin tümü de , \% 1, \% 5 ve $\% 10$ anlamlılık düzeylerinde durağan değildirler yani seriler birim kök içermektedir. Düzey değerlerinde durağan olmayan serilerin birinci farkları alındığında, $t$ istatistikleri tablo değerlerinden mutlak değerce büyük olduğu için durağan hale geldiği görülmektedir. $\mathrm{Bu}$ sonuçlar $\mathrm{ADF}$ ve $\mathrm{PP}$ testlerinden farklı bir sonuç içermemektedir.

\section{Eşbütünleşme Testi Bulguları}

Yapısal kırılma altında serilerin birinci fakları alındığında serilerin durağan hale geldiğinin belirlenmesinden dolayı değişkenler arasında yapısal kırılma altında uzun dönemli bir ilişkiyi tespit edebilmek için Gregory-Hansen eşbütünleşme testi yapılmıştır. Minimum ADF test istatistikleri ve kırılma dönemleri Tablo 4'te görülmektedir. Tablo 4'de yer alan ADF istatistik değerleri, Gregory ve Hansen (1996) çalışmasında yer alan tablo kritik değerleri ile karşılaştırılmıştır.

Tablo 4: Gregory-Hansen Eşbütünleşme Testi Sonuçları

\begin{tabular}{|c|c|c|c|c|}
\hline Model & $\begin{array}{c}\text { Kırılma } \\
\text { Dönemi }\end{array}$ & $\begin{array}{c}\text { ADF } \\
\text { İstatistiği }\end{array}$ & $\begin{array}{c}\text { Kritik } \\
\text { Değerler \%1 }\end{array}$ & $\begin{array}{c}\text { Kritik } \\
\text { Değerler \%5 }\end{array}$ \\
\hline Sabitte Kırılma & 2000 & $-7,42$ & $-5,44$ & $-5,50$ \\
\hline $\begin{array}{c}\text { Sabitte ve } \\
\text { Trendde } \\
\text { Kırılma }\end{array}$ & 2001 & $-8,71$ & $-5,80$ & $-5,29$ \\
\hline Rejim Değişimi & 2008 & $-9,84$ & $-5,80$ & $-4,92$ \\
\hline
\end{tabular}

$\mathrm{H}_{\mathrm{o}}$ : Yapısal kırılmalar altında eşbütünleşme yoktur.

$\mathrm{H}_{1}$ : Yapısal kırılmalar altında eşbütünleşme vardır.

Bütün modeller için hesaplanan minimum ADF istatistiği mutlak değer olarak kritik değerlerden büyük olduğundan seriler arasında yapısal kırılmalar altında eşbütünleşme olduğunu ifade eden $\mathrm{H}_{1}$ hipotezi kabul edilir. Bu yüzden de $\mathrm{H}_{0}$ hipotezi reddedilecektir. Dolayısıyla Gregory-Hansen testi sonuçlarına göre değişkenler arasında uzun dönemli bir ilişki olduğu görülmektedir. Ayrıca, üç model için sırasıyla 2000, 2001 ve 2008 yıllarında yapısal kırılma söz konusudur.

\section{Nedensellik Testi}

Seriler arasında eş bütünleşme ilişkisi tespit edildikten sonra çalışmanın bu bölümünde kısa dönemde petrol tüketimi ile GSYIHH arasındaki nedensellik ilişkisinin varlığ ve yönü analiz edilecektir. Analiz işleminde Toda-Yamamoto yöntemine dayalı nedensellik analizi sonuçları kullanılacaktır. Elde edilen sonuçlar Tablo 5'te yer almaktadır. 
Tablo 5: Toda Nedensellik Testi Sonuç Tablosu

\begin{tabular}{|c|c|c|c|}
\hline Bağımlı değişken: LNPT & \multicolumn{1}{l|}{ sd } & olasılık \\
\hline & Ki-kare & 1 & 0.9972 \\
\hline LNDKR & $1.25 \mathrm{E}-05$ & 1 & 0.05500 \\
\hline LNFO & 0.357343 & 2 & 0.8334 \\
\hline GENEL & 0.364521 & sd & olasılık \\
\hline Bağımlı değişken: LNGSYIHH & 1 & 0.01367 \\
\hline \multicolumn{4}{|l|}{ Ki-kare } \\
\hline LNENF & 2.214269 & 1 & 0.1804 \\
\hline LNDKR & 3.056361 & 2 & 0.2145 \\
\hline GENEL & 3.079315 & & \\
\hline
\end{tabular}

Toda-Yamamoto nedensellik testi sonuçlarına göre, $\% 5$ anlamlılık düzeyinde petrol tüketiminden, reel GSYİH'ya doğru tek yönlü bir nedensellik ilişkisi mevcuttur.

\section{SONUÇ}

Bu çalışma esas olarak petrol tüketimi değişkeni ile reel GSYİH arasındaki ilişkiyi belirlemektedir ve ilgili geniş literatüre konuyu Türkiye açısından inceleyerek katkıda bulunmaktadır

Bu çalışmada, 1980-2016 yılları arasındaki petrol tüketimi ve reel GSYİH yıllık verileri kullanılarak, değişkenler arasındaki ilişkiyi saptamak amacıyla gerekli ekonometrik analizler yapılmıştır. Yapılan analizlerde değişkenleri arasında uzun dönemli bir ilişkiye rastlanılmıştır. Ayrıca değişkenler arasındaki nedensellik ilişkisini belirlemek amacıyla Toda Yamamoto nedensellik testi uygulanmıştır. Bunun sonucunda, petrol tüketiminden, reel GSYİH'ya doğru tek yönlü bir nedensellik ilişkisi belirlenmiştir. Bu nedensellik ilişkisi "büyüme hipotezi" olarak adlandırılmaktadır. Bu hipotez, enerji tüketimindeki artış ekonomik büyümeye katkı sağlayabilirken, enerji tüketimindeki sınırlamalar ekonomik büyüme üzerinde ters etkiye sahip olabileceğini gösterir. Aynı zamanda bu hipotez, enerji tüketiminin emek ve sermayeyi tamamlayıcı olarak hem doğrudan hem de dolaylı olarak üretim sürecinde ekonomik büyümede önemli bir rol oynadığını gösterir. Politika yapıcılar enerji tüketimini arttırmaya yönelik politikalar uygulaması ekonomik büyümeyi de artıracaktır.

Literatürü incelediğimizde, petrol tüketimi ve reel GSYİH arasındaki ilişkiyi inceleyen pek çok teorik ve ampirik çalışmayla karşılaşmaktayız. Söz konusu çalışmaların bir kısmında, değişkenler arasında çift yönlü bir nedensellik ilişkisi olduğu sonucuna ulaşılmıştır. Diğer bir kısım da ise tek yönlü bir nedensellik ilişkisi olduğu sonucuna varılmıştır. Yaptığımız çalışmanın sonucu da, petrol tüketimi ve reel GSYİH arasında tek yönlü bir nedensellik ilişkisini ortaya koyduğu için, bu görüşün hakim olduğu literatüre katkıda bulunmuştur. Çalışmayı benzer çalışmalarla karşılaştırdığımızda, çalışmanın sonucu, Ceylan ve Başer (2011)' in 1965-2011 yılları arası ile Hepaktan ve Sertkaya (2016)'nın 1970-2016 yılları arasındaki bulgularına benzer sonuçlar taşımaktadır. 


\section{KAYNAKÇA}

Aktaş, C Ve Yılmaz, V . (2008). Türkiye'de Petrol Tüketimi Ve Ekonomik Büyüme Arasindaki Nedensellik Ilişkisi. Kocaeli Üniversitesi Sosyal Bilimler Enstitüsü Dergisi, (15), 45-55.

Al-Mulali, U. (2011). "Oil Consumption, Co2 Emission And Economic Growth İn Mena Countries". Energy, 36(10), 6165-6171.

Amano, R. A. And Van Norden, S. (1998). Oil Prices And The Rise And Fall Of The Us Real Exchange Rate. Journal Of International Money And Finance, 17, 299-316.

Aqeel, A. And Butt, M.S. (2001). The Relationship Between Energy Consumption And Economic Growth İn Pakistan. Asia-Pacific Development Journal, 8(2), 101-109.

Ceylan, R. Ve Başer, S. (2014), “Türkiye'de Petrol Tüketimi İle Reel Gsyih Arasındaki Uzun Dönem İlişkinin Johansen Eşbütünleşme Yöntemi İle Analiz Edilmesi” Business And Economics Research Journal, 5(2), 47-60.

Çemrek, F.,Ve Burhan, E. (2014). Petrol Tüketiminin Ekonomik Büyüme Üzerindeki Etkisinin Panel Veri Analizi İle İncelenmesi: Avrupa Birliği Ülkeleri Ve Türkiye Örneği. Uluslararası Alanya İşletme Fakültesi Dergisi, 6(3), 47-58.

Çukuçayır, M.A., Ve Sağır, H. (2008). Enerji Sorunu, Çevre Ve Alternatif Enerji Kaynakları, Sosyal Bilimler Enstitüsü Dergisi, Sayı 20, 257-258.

Demir, A. (1981). Çağdaş Teknolojik Gelişmeler Sosyo Ekonomik Etkileri, Ankra Üniversitesi Siyasal Bilgiler Fakültesi Yayınları, Yayın No:472, Ankara.

Ghosh, S. (2009). Import Demand Of Crude Oil And Economic Growth: Evidence From India. Energy Policy, 37(2), 699-702

Gregory, A.W. And Hansen B.E. (1996), "Residual-Based Tests For Cointegration İn Models With Regime Shifts", Journal Of Econometrics, 70(1): 99-126.

Gujarati, D. (2004). Basic Econometrics, Fourth Edition, Mcgraw Hill Companies. New York.

Hepektan, E. Ve Sertkaya, Y . (2016). Türkiye'de Elektrik Tüketimi, Kişi Başına Gsyih, Co2 Emisyonu Ve Petrol Tüketimi İlişkisi. Yalova Üniversitesi Sosyal Bilimler Dergisi, 6 (12), 163-182.

Hossein, A., Yazdan, G. F., Ve Ehsan, A. G. (2012). "The Relationship Between Energy Consumption, Energy Prices And Economic Growth: Case Study (Opec Countries)". Opec Energy Review, 36(3), 272-286.

Iwayemi, A., Adenikinju, A., And Babatunde, M. A. (2010). Estimating Petroleum Products Demand Elasticities İn Nigeria: A Multivariate Cointegration Approach. Energy Economics, 32(1), 73-85.

Jimenez-Rodriguez, R And Sanchez, M. (2004). Oil Price Shocks And Real Gdp Growth: Empirical Evidence For Some Oecd Countries. Applied Economics, 37(2), 201-228.

Kandel, A., Sheridan, M., And Mcauliffe, P. (2008). A Comparison Of Per Capita Electricity Consumption İn The United States And California. Proceedings Of The 2008 Aceee Summer Study On Energy Efficiency İn Buildings, 8-123.

Lutkepohl, H. Ve Kratzig, M. (2004). Applied Time Series Econometrics. Cambridge: Cambridge University Press.

Mehrara, M. And Musai, M. (2012). Granger Causality Between Electricity Consumption And Economic Growth İn Oil-Dependent Countries. Universal Journal Of Management And Social Sciences, 2(6), 134-139.

Öztürk, İ. (2010). A Literatüre Survey On Energy-Growth Nexus, Energy Policy, 38, 340-349.

Park S-Y, Yoo S-H. (2014) The Dynamics Of Oil Consumption And Economic Growth İn Malaysia. Energy Policy 66, 218-23.

Prasad, A., Narayan P. K. And Narayan J. (2007). Exploring The Oil Price And Real Gdp Nexus For A Small İsland Economy The Fiji İslands. Energy Policy, 35, 6506-6513.

Soytaş, U.,Ve Sarı, R. (2003). "Energy Consumption And Gdp: Causality Relationship İn G-7 Countries And Emerging Markets", Energy Economics, 25, Pp.33.-37.

Şentürk, M. Ve Akbaş Y. E, (2014), "İşsizlik-Enflasyon Ve Ekonomik Büyüme Arasındaki Karşılıklı İlişkinin Değerlendirilmesi: Türkiye Örneği”’ Journal Of Yasar University, 9(34) 5820-5832 
Toda, H.Y. And Yamamoto, T. (1995). Statistical İnferences İn Vector Autoregressions With Possibly İntegrated Processes, Journal Of Econometrics, Volume:66, 225-50.

Uçak., S. And Usupbeyli, A. (2015). Türkiye'de Petrol Tüketimi Ve Ekonomik Büyüme Arasındaki Nedensellik İlişkisi. Ankara Üniversitesi Sbf Dergisi, 70(3), 45-55.

Yang, H. Y. (2000). "A Note On The Causal Relationship Between Energy And Gdp İn Taiwan". Energy Economics, 22(3), 309-317.

Yardımcıoğlu, F. Ve Beşel F. (2013), "İşsizlik-Petrol Fiyatları İlişkisi: Yapısal Kırılmalar Altında Türkiye Örneği (1980-2012).” Electronic Turkish Studies Cilt: 8. Sayı:8, Ss. 2197-2211.

Yılancı, V. Ve Özcan, B. (2010), "Yapısal Kırılmalar Altında Türkiye İçin Savunma Harcamaları İle Gsmh Arasındaki İlişkinin Analizi”, C.Ü. İktisadi Ve İdari Bilimler Dergisi, 11(1): 21-33.

Zivot, E. Ve Andrews, D. (1992). Further Evidence Of Great Crash, The Oil Price Shock And Unit Root Hypothesis, Journal Of Business And Economic Statistics, 10(3), 251-270.

Zou, G., Chau, K.W., (2006). Short And Log-Run Effects Between Oil Consumption And Economic Growth İn China”, Energy Policy, 34 (18): 3644-3655.

Http://Www.Bp.Com/Content/Dam/Bp-Country/Tr_Tr/Pdf/Bp_Enerji_Statistikleriraporu 2016 Bb.Pdf, (12.06.2017)

Http://Www.Enerji.Gov.Tr/Tr-Tr/Sayfalar/Petrol, (12.06.2017)

\section{SUMMARY}

There are many by-products of petroleum derivatives using actual products being obtained from petroleum and is used in every fields of our daily life. Similar to the other countries in the world, this trend is equally observed as a continuous increase of oil consumption to their limits in Turkey. In fact, petroleum consumption is mostly in the areas of industry, transportation, residential and individual consumption, which are dependent on our technological developments.

In this study, there will be an econometric time series analysis in order to examine the relationship between oil consumption in Turkey with real gross domestic product (GDP). The relationship between oil consumption and real GDP is examined using the annual time series data for 1980-2016. Petroleum consumption from the data used in the study was obtained from the Word Bank and from the real GDP TURKSTAT website. LNPT and LNGSHIH, abbreviated expressions used in the analyzes show the natural logarithms of the variables of oil consumption and real GDP respectively.

When the annual oil consumption and real GDP graphs between 1980 and 2016 are examined, we can see that the oil consumption series has steadily increased from 1981 to 2016 and reached its highest value in 2016. When examining the real GDP series, a fluctuation is recorded, although there is usually an increasing course, and there are many breaks. The series, which tended to increase until 2015, showed a sharp increase in 2015. Finally, the highest value is reached in 2016. Even if there are increases and decreases in the series, structural breaks are also seen in some periods.

In this study, necessary econometric analysis were conducted to determine the relationship between variables using oil consumption and real GDP annual data between 1980 and 1616. In these analysis, there is a long-term relationship between the variables. In addition, the Toda Yamamoto causality test was applied to determine the causality relationship between these variables. As a result, a one-way causality relation from petroleum consumption to real GDP has been determined. 
This causality relation is called "growth hypothesis". This hypothesis indicates that the increase in energy consumption may contribute to economic growth while the limitations in energy consumption could have an adverse effect on economic growth. Conclusively, this hypothesis shows that the energy consumption plays an important role in economic growth both directly and indirectly as a complement to labour and capital in the production process. The govermental policies of increasing energy consumption will also increase economic growth.

When the current literatures are examined, we record many theoretical and empirical studies that do not address this relationship between oil consumption and real GDP. As part of some studies, it is concluded that there is a bi-directional causality relationship between the variables. The other relevant studies are the result of a one-way causality relationship. The result of our work also contributed to the literature that this view prevails, since it reveals a one-way causality relationship between oil 